\title{
Evaluasi Pengelolaan Limbah Padat B3 Fasilitas Puskesmas di Kabupaten Sidoarjo
}

\author{
Gloria Mayonetta dan IDAA Warmadewanthi \\ Jurusan Teknik Lingkungan, Fakultas Teknik Sipil dan Perencanaan, Institut Teknologi Sepuluh \\ Nopember (ITS) \\ Jl. Arief Rahman Hakim, Surabaya 60111 Indonesia \\ e-mail: mayonetta.gloria@gmail.com
}

\begin{abstract}
Abstrak - Peningkatan pelayanan kesehatan di Kabupaten Sidoarjo dalam bentuk program berobat gratis seperti Badan Penelenggara Jaminan Sosial (BPJS) Kesehatan meningkatkan kunjungan pasien ke Puskesmas. Peningkatan kunjungan secara tidak langsung mempengaruhi laju timbulan dan karakteristik limbah padat B3 Puskesmas. Penelitian dilakukan di Puskesmas Kabupaten Sidoarjo yang meliputi Puskesmas rawat inap, rawat jalan dan pembantu. Evaluasi pengelolaan meliputi kegiatan pengemasan pengumpulan, penyimpanan, pengangkutan, dan pengolahan. Pengukuran laju timbulan dan komposisi limbah padat B3 dilakukan selama 8 hari pada 4 Puskesmas rawat inap, 3 Puskesmas rawat jalan, dan 9 Puskesmas pembantu (Pustu). Rata-rata laju timbulan Puskesmas rawat inap adalah 60,47 g/pasien.hari dengan $59 \%$ persen komposisi limbah merupakan botol infus bekas. Rata-rata laju timbulan Puskesmas rawat jalan adalah $6,37 \mathrm{~g}$ /pasien.hari dengan $73 \%$ persen komposisi limbah merupakan infeksius non benda tajam. Rata-rata laju timbulan Pustu adalah 1,97 g/pasien.hari dengan 39\% persen komposisi limbah merupakan infeksius benda tajam.
\end{abstract}

Kata Kunci- limbah medis, limbah padat B3, Sidoarjo, Puskesmas.

\section{PENDAHULUAN}

$\mathrm{S}$ IDOARJO merupakan kabupaten dengan pertumbuhan penduduk tertinggi ketiga di Jawa Timur. Pertumbuhan penduduk di Kabupaten Sidoarjo diikuti dengan peningkatan di berbagai bidang, salah satunya pelayanan kesehatan di Puskesmas. Peningkatan pelayanan Puskesmas di Sidoarjo dalam bentuk program berobat gratis seperti Jamkesmas, Jamkesda dan BPJS kesehatan maupun perubahan Puskesmas rawat jalan menjadi rawat inap secara tidak langsung akan mempengaruhi komposisi dan laju timbulan limbah padat B3. Peningkatan timbulan limbah padat B3 yang terjadi tidak diimbangi dengan peningkatan sistem pengelolaan yang baik.

Peningkatan laju timbulan limbah padat B3 (limbah padat medis) yang dihasilkan Puskesmas harus diimbangi dengan sistem pengelolaan limbah padat B3 yang baik agar tidak mencemari lingkungan. Keputusan Menteri Kesehatan Nomor 1204 Tahun 2004 tentang Persyaratan Kesehatan Lingkungan Rumah Sakit menyatakan fasilitas kesehatan wajib untuk mengelola limbahnya. Pengelolaan limbah medis telah dilakukan di Puskesmas Kabupaten Sidoarjo, namun terjadi permasalahan di semua tahap pengelolannya (from cradle to grave). Pengambilan limbah padat B3 oleh pihak pengolah di salah satu Puskesmas di Kabupaten Sidoarjo dilakukan setiap $25 \mathrm{~kg}$, tanpa memperhatikan batas waktu penyimpanan. Penyimpanan limbah padat B3 pada musim hujan maksimal 48 jam dan pada musim kemarau maksiman 24 jam [1]. Pada tahun 2015 di Puskesmas yang sama, pengambilan limbah padat B3 oleh pihak pengolah dilakukan hanya sekali dalam beberapa bulan. Di sisi lain, beberapa Puskesmas sudah memiliki insinerator, namun karena tidak memiliki ijin pengolahan limbah B3, insinerator tidak dapat digunakan sebagaimana mestinya.

Di negara-negara berkembang, limbah medis belum mendapat perhatian secara khusus dan masih dibuang bersama dengan limbah domestik [2]. Limbah Puskesmas mempunyai potensi besar untuk mencemari lingkungan, menimbulkan kecelakaan, dan penularan penyakit apabila pengelolaan limbah medis belum sesuai dengan peraturan yang berlaku [3]. Rujukan [4] mengemukaan resiko kesehatan akibat limbah medis, yakni resiko terjadinya trauma, resiko terjadi infeksi, resiko zat kimia, resiko ledakan/terbakar, dan resiko radioaktif.

Limbah Puskesmas terdiri dari limbah non medis dan limbah medis. Limbah non medis mempunyai karakteristik seperti limbah yang ditimbulkan oleh lingkungan rumah tangga (domestik) dan lingkungan masyarakat pada umumnya [5]. Limbah medis antara lain limbah infeksius, patologi, benda tajam, farmasi, sitotoksis, kimia, radioaktif, dan limbah dengan kandungan logam berat yang tinggi [1].

Limbah medis yang dihasilkan oleh pelayanan kesehatan sebesar 10-25\% dan sisanya sebesar 75 - 90\% merupakan limbah domestik [6]. Walaupun limbah medis yang dihasilkan lebih sedikit dari limbah domestik, resiko terhadap lingkungan berpotensi lebih besar apabila tidak ditangani dengan baik. Penelitian yang dilakukan di Brookdale University Hospital and Medical Center menyimpulkan bahwa 70-80\% limbah infeksius dari rumah sakit merupakan limbah non infeksius yang tercampur dengan limbah infeksius akibat pengelolaan yang buruk [7].

Berdasarkan latar belakang tersebut, maka diperluakan suatu evaluasi pengelolaan limbah padat B3 Puskesmas di Kabupaten Sidoarjo. Selain itu penelitian ini juga bertujuan untuk mengidentifikasi laju timbulan dan karakteristik limbah padat B3 Puskesmas di Kabupaten Sidoarjo serta memberikan rekomendasi pengelolaan yang sesuai dengan peraturan yang berlaku. 


\section{METODE PENELITIAN}

\section{A. Pengambilan Data}

Pengambilan data dilakukan dengan metode kuisioner dan pengamatan/pengukuran secara langsung. Pada penelitian ini, terdapat dua jenis data yang akan digunakan yaitu data primer dan data sekunder. Metode kuisioner digunakan untuk memperoleh data sekunder. Data sekunder yang dibutuhkan adalah jumlah pasien/pengunjung Puskesmas, fasilitas yang tersedia, kondisi eksisting pengelolaan, spesifikasi alat pengelolaan yang digunakan, serta data Puskesmas pembantu (Pustu). Metode pengamatan/pengukuran secara langsung digunakan untuk memperoleh data primer berupa kondisi eksisting pengelolaan, laju timbulan dan komposisi limbah padat B3 Puskesmas. Alat dan bahan yang dibutuhkan untuk pengukuran laju timbulan adalah (1) timbangan portable, (2) plastik/trash bag, dan (3) alat pelindung diri (APD).

\section{B. Pelaksanaan Penelitian}

Penelitian ini diawali dengan pengumpulan data melalui penyebaran kuisioner ke 26 Puskesmas induk di Kabupaten Sidoarjo. Puskesmas induk terdiri dari 15 Puskesmas rawat inap dan 11 Puskesmas rawat jalan. Data yang didapatkan berupa kondisi eksisting pengelolaan limbah padat B3 yang meliputi penilahan, pengemasan, pengumpulan dan penyimpanan. Pengolahan limbah padat B3 dilakukan oleh pihak ketiga yaitu PT PRIA.

Pengukuran laju timbulan dan komposisi limbah padat B3 dilakukan pada 7 Puskesmas induk. Penentuan jumlah ini menggunakan metode stratified random sampling dengan varians jumlah pasien. Penentuan Puskesmas yang dipilih untuk pengukuran menggunakan metode simple random sampling berdasarkan fasilitas pelayanan yang ditawarkan. Puskesmas yang diukur laju timbulan dan komposisinya adalah 4 Puskesmas rawat inap yaitu Sukodono, Taman, Sedati, dan Waru, serta 3 Puskesmas rawat jalan yaitu Sidoarjo, Gedangan dan Candi. Terdapat 9 Pustu yang disampling yaitu Punggul, Kalang Anyar, Pabean, Ngingas, Tambak Sumur, Wage, Jogosatru, Plumbungan, dan Bluru Kidul. Pustu dipilih dengan metode simple random sampling dari Puskesmas induk yang diukur laju timbulannya.

Pada penelitian ini juga akan dilakukan kunjungan lapangan ke PT PRIA untuk melihat proses pengolahan limbah padat B3 Puskesmas dengan insinerator. Data pengolahan diperoleh berdasarkan hasil pengamatan dan wawancara serta data sekunder dari PT PRIA. Data sekunder berupa spec insinerator, suhu serta waktu pengoperasian insinerator.

\section{HASIL DAN PEMBAHASAN}

\section{A. Identifikasi Limbah Padat B3 Puskesmas}

Limbah padat B3 yang dihasilkan oleh Puskesmas berasal dari kegiatan medis. Jenis limbah yang dihasilkan adalah limbah infeksius benda tajam, infeksius non benda tajam, toksik farmasi, dan botol infus bekas. Limbah infeksius benda tajam terdiri dari jarum suntik dan pisau bedah. Limbah infeksius non benda tajam terdiri dari kasa, kapas, diapers, tissue, handscoen, dan botol plastik bekas ludah penderita TBC. Limbah toksik farmasi terdiri dari sisa bungkus obat, obat yang sudah kadaluarsa, botol obat/reagen yang dipakai di laboratorium, ampul dan vial.

\section{1) Komposisi Limbah Padat B3}

Berikut ini merupakan persentase komposisi limbah padat B3 di Puskesmas rawat inap, rawat jalan, dan Pustu yang disajikan dalam Gambar 1, Gambar 2, dan Gambar 3.

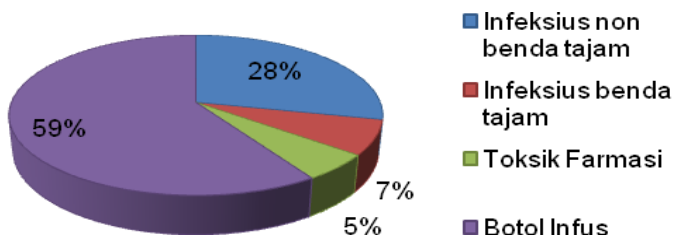

Gambar 1. Persentase Komposisi Limbah Padat B3 Puskesmas Rawat Inap

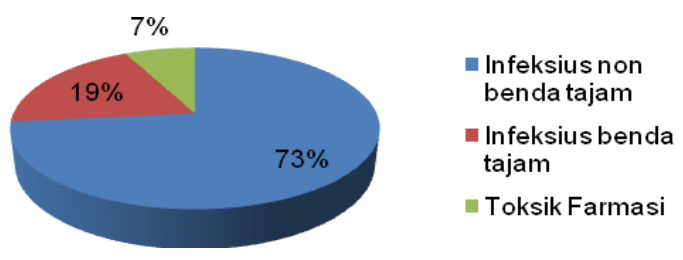

Gambar 2. Persentase Komposisi Limbah Padat B3 Puskesmas Rawat Jalan

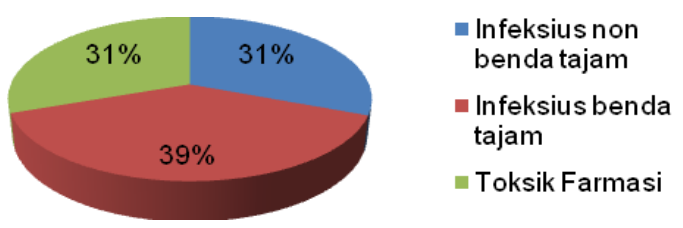

Gambar 3. Persentase Komposisi Limbah Padat B3 Pustu

2) Laju Timbulan Limbah Padat B3

Berikut ini merupakan hasil pengukuran laju timbulan limbah padat B3 di 7 Puskesmas induk yang disajikan dalam Tabel 1. Hasil pengukuran laju timbulan di Pustu diasjikan pada Tabel 2.

Tabel 1.

Laju Timbulan Limbah Padat B3 Puskesmas Induk

Puskesmas $\quad \begin{gathered}\text { Timbulan } \\ \text { (g/pasien.hari) }\end{gathered}$

\begin{tabular}{cc}
\multicolumn{2}{c}{ RAWAT INAP } \\
Sukodono & 58.08 \\
Taman & 94.03 \\
Sedati & 39.70 \\
\hline \hline
\end{tabular}




\begin{tabular}{cc}
\hline \hline Waru & 50.06 \\
Rata-rata & $\mathbf{6 0 . 4 7}$ \\
RAWAT JALAN \\
Sidoarjo & 7.34 \\
Gedangan & 6.25 \\
Candi & 5.51 \\
Rata-rata & $\mathbf{6 . 3 7}$ \\
\hline \hline
\end{tabular}

Tabel 2.

Laju Timbulan Limbah Padat B3 Pustu

\begin{tabular}{cccc}
\hline \hline No & Pustu & $\begin{array}{c}\text { Puskesmas } \\
\text { Induk }\end{array}$ & $\begin{array}{c}\text { Rata-rata timbulan } \\
\text { (g/pasien.hari) }\end{array}$ \\
\hline 1 & Punggul & Gedangan & 4.20 \\
2 & Kalang Anyar & Sedati & 1.25 \\
3 & Pabean & & 0.56 \\
4 & Ngingas & Waru & 0.34 \\
5 & Tambak Sumur & Taman & 1.68 \\
6 & Wage & Sukodono & 0.27 \\
7 & Jogosatru & 5.40 \\
8 & Plumbungan & Sidoarjo & 0.69 \\
9 & Bluru Kidul & 1.97 \\
\hline \hline
\end{tabular}

\section{B. Kondisi Eksisting Pengelolaan Limbah Padat B3}

Pengelolaan limbah padat B3 yang dilakukan oleh Puskesmas meliputi pemilahan, pengemasan, pengumpulan dan penyimpanan. Pengangkutan dan pengolahan limbah padat B3 dilakukan oleh PT PRIA dengan metode insinerasi. Berikut ini merupakan uraian kondisi eksisting pengelolaan limbah padat B3.

1) Pemilahan

Pemilahan limbah dilakukan berdasarkan jenis limbah yaitu infeksius benda tajam, infeksius non benda tajam, toksik farmasi dan botol infus bekas. Pemilahan dilakukan dengan menyediakan kemasan yang berbeda bagi setiap jenis limbah. Puskesmas memberikan label "limbah medis" pada wadah limbah infeksius benda tajam dan toksik farmasi.

Walaupun sudah dilakukan pemilahan, pada prakteknya masih ditemukan sampah makanan, sisa bungkus makanan dan kertas terdapat pada kemasan limbah medis. Limbah jarum suntik masih sering ditemukan tercampur dalam wadah limbah infeksius non benda tajam.

\section{2) Pengemasan}

Puskesmas menggunakan safety box sebagai kemasan limbah infeksius benda tajam. Limbah padat B3 jenis lainnya dikemas dengan tempat sampah plastik yang dilengkapi penutup. Akibat persediaan yang terbatas, beberapa Puskesmas kembali menggunakan safety box yang telah penuh ataupun menggunakan kemasan kardus dan botol air mineral bekas.

Hasil pengamatan pada 33 ruangan yang menghasilkan limbah medis, sebanyak 1 ruangan belum menyediakan kemasan limbah medis dan 7 ruangan menggunakan kemasan tanpa penutup. Sebanyak 6 dari 33 ruangan belum menyediakan kemasan limbah infeksius benda tajam.

\section{3) Pengumpulan}

Pengumpulan limbah padat B3 dari setiap ruangan di Puskesmas induk dilakukan setiap hari untuk limbah infeksius non benda tajam, toksik farmasi dan botol infus bekas. Pengumpulan dilakukan sebelum ataupun setelah pelayanan administrasi. Pengumpulan dilakukan setiap hari agar tidak terjadi penumpukan dan mencegah kontaminasi ruang pelayanan medis. Limbah infeksius benda tajam dikumpulkan apabila safety box telah penuh.

Berdasarkan hasil pengamatan, frekuensi pengumpulan di Pustu dilakukan lebih dari 7 hari. Limbah padat B3 dari Pustu akan dibawa ke Puskesmas induk untuk disimpan di TP S B3 sebelum diolah. Pengumpulan dilakukan lebih dari 7 hari karena limbah padat B3 yang dihasilkan Pustu sangat sedikit. Berdasarkan hasil pengamatan, dalam beberapa hari Pustu bisa tidak menghasilkan limbah sama sekali. Hal ini dikarenakan adanya kebijakan tidak tertulis yang diterapkan sebagian Puskesmas mengenai pembatasan kegiatan injeksi terutama di Pustu.

Pada saat proses pengumpulan limbah, petugas pengumpulan pada umumnya hanya menggunakan handscoen dan masker. Proses pengumpulan tidak menggunakan trolly khusus. Petugas akan mengangkat plastik kemasan berisi limbah dan mengganti dengan plastik yang baru. Plastik berisi limbah padat B3 dari setiap ruangan dipegang dan dibawa secara langsung menuju TPS.

\section{4) Penyimpanan}

Penyimpanan limbah padat B3 oleh Puskesmas Induk di TPS B3 dilakukan hingga berbulan bulan. Pembayaran minimum untuk satu kali pengambilan limbah padat B3 oleh pengolah adalah $25 \mathrm{~kg}$. Laju timbulan rata-rata Puskesmas dalam satu hari kurang dari $25 \mathrm{~kg}$. Sehingga Puskesmas menunggu hingga limbahnya mencapai $25 \mathrm{~kg}$ atau lebih, lalu kemudian memanggil pengolah untuk mengangkut limbah padat B3.

Berdasarkan hasil pengamatan, 1 dari 26 Puskesmas belum memiliki TPS B3. Limbah padat B3 diletakkan di area belakang Puskesmas di ruang terbuka. Empat lokasi TPS B3 berada di dalam bangunan Puskesmas dan merupakan lokasi yang sering dilewati oleh pasien dan pengunjung Puskesmas. Satu Puskesmas menggunakan ruangan incinerator yang sudah tidak terpakai, dan satu Puskesmas memiliki TPS B3 yang berada di lantai 2 Puskesmas.

5) Pengangkutan 
Pengangkutan limbah padat B3 dari Pustu ke Puskesmas induk tidak menggunakan kendaraan khusus. Pengangkutan limbah padat B3 dari Puskesmas induk ke pengolah menggunakan kendaraan pick up yang tertutup dan sudah dilengkapi dengan simbol. Petugas hanya menggunakan APD berupa hanscoen saat memasukkan limbah ke dalam kendaraan pengangkut. Berdasarkan hasil wawancara, petugas sudah mendapatkan training sebelumnya perihal penanganan limbah medis.

\section{6) Pengolahan}

Terdapat 2 Puskesmas yang membakar limbah infeksius non benda tajam sendiri dan terdapat 1 Puskesmas yang membakar limbah toksik farmasi sendiri. Salah satu Puskesmas membakar di dalam tungku, dan 2 Puskesmas lainnya membakar secara open burning. Masih banyak ditemukan Pustu yang membakar limbah infeksius non benda tajam secara open burning.

Pengolahan limbah medis oleh PT PRIA menggunakan 2 unit insinerator dengan tipe Reciprocating Grate Static Incinerator. Insinerator memiliki kapasitas $350 \mathrm{~kg} / \mathrm{jam}$. Rata-rata penggunaan suhu insinerator pada chamber 1 adalah $792^{\circ} \mathrm{C}$ dan $1019^{\circ} \mathrm{C}$ pada chamber 2. Rata-rata limbah medis yang dibakar adalah $48 \mathrm{~kg} / 10$ menit. Berdasarkan hasil uji emisi, efisiensi pembakaran adalah 99,99\%. Alat kontrol emisi berupa wet scrubber.

\section{Evaluasi Kondisi Eksisting Pengelolaan Limbah Padat B3}

1) Komposisi Limbah Padat $B 3$

Komposisi limbah B3 terbanyak Puskesmas rawat inap adalah botol infus bekas sebesar 59\%. Botol infus yang tidak habis terpakai dibuang dalam keadaan dimana cairan infus di dalamnya masih tersisa. Sehingga cairan ini membuat berat limbah botol infus bekas meningkat.

Apabila botol infus tidak dimasukkan ke dalam perhitungan persentase kompsisi maka limbah infeksius non benda tajam menempati persentase tertinggi yaitu 70\%. Persentase komposisi dapat dilihat pada Gambar 4.
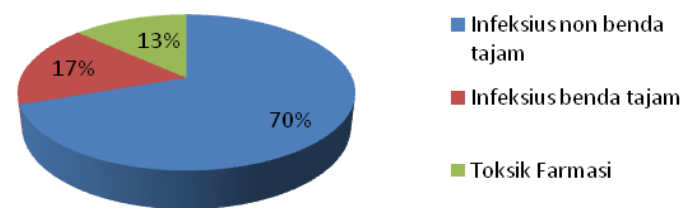

Gambar 4. Persentase Komposisi Limbah Padat B3 Puskesmas Rawat Inap tanpa Limbah Botol Infus

Komposisi limbah tertinggi pada Puskesmas rawat jalan adalah limbah infeksius non benda tajam sebesar $73 \%$. Persentase limbah infeksius non benda tajam pada Puskesmas rawat inap dan rawat jalan tidak jauh berbeda. Perbedaan kedua tipe Puskesmas ini hanya terletak pada fasilitas pelayanan rawat inap saja, dimana pada fasilitas inilah limbah botol infus dihasilkan. Komposisi ini memiliki kesamaan dengan Puskesmas di Surabaya Timur dan Surabaya Barat [8][9].

2) Laju Timbulan Limbah Padat B3

Berdasarkan pengukuran di 7 Puskesmas induk dan 9 Pustu, didapatkan hasil laju timbulan sebagai berikut.

- Rawat Inap $=60,47 \mathrm{~g} /$ pasien.hari

- Rawat Jalan $=6,37 \mathrm{~g} /$ pasien.hari

- Pustu = $1,97 \mathrm{~g} /$ pasien.hari

Puskesmas induk di Surabaya Timur dan Surabaya Barat masing masing memiliki laju timbulan $3,97 \mathrm{~g} /$ pasien.hari dan $1,5 \mathrm{~g} /$ pasien.hari [8][9]. Terdapat perbedaan yang cukup jauh apabila dibandingkan dengan Puskesmas rawat inap dengan laju timbulan 60,47 g/pasien.hari. Penelitian yang dilakukan di Surabaya Timur dan Barat tidak menyertakan limbah botol infus dalam perhitungan laju timbulannya. Perbedaan kebijakan pemerintah pada saat pengukuran dilakukan juga mempengaruhi laju timbulan. Penelitian di Surabaya Timur dan Barat dilaksanakan pada waktu dimana belum ada Badan Penyelenggara Jaminan Sosial (BPJS). Sedangkan pengukuran laju timbulan di Kabupaten Sidoarjo dilakukan setelah program BPJS diberlakukan. Keberadaan BPJS berpengaruh besar dalam peningkatan kunjungan pasien ke Puskesmas yang secara tidak langsung meningkatkan laju timbulan limbah padat B3. Laju timbulan limbah padat B3 di Pustu adalah 1,97 g/pasien.hari. Hasil ini tidak berbeda jauh dengan rujukan [8][9] yang menemukan laju timbulan Pustu sebesar 1,26 g/pasien.hari.

Total limbah padat B3 yang dihasilkan oleh Puskesmas rawat inap di Kabupaten Sidoarjo adalah 7,4 kg/hari dan $3,02 \mathrm{~kg} / \mathrm{hari}$ tanpa botol infus. Puskesmas rawat jalan sebesar 1,13 kg/hari dan Pustu 0,033 kg/hari. Penelitian di Kabupaten Pati oleh rujukan [10] menyebutkan bahwa range laju timbulan Puskesmas berkisar antara 0,5 hingga 5 $\mathrm{kg} /$ hari serta di Kabupaten Jember sebesar $0.73 \mathrm{~kg} / \mathrm{hari}$ [3]. Laju timbulan limbah padat B3 Puskesmas rawat inap di Kabupaten Sidorajo masih termasuk dalam range laju timbulan di Kabupaten Pati dan sedikit lebih tinggi dari laju timbulan di Pukesmas Kabupaten Jember. Penyebabnya adalah karena jenis pelayanan medis yang ditawarkan berbeda. Rujukan [11] menyebutkan bahwa laju timbulan limbah medis sangat dipengaruhi oleh besar dan tipe dari fasilitas kesehatan. Selain kedua hal tersebut, rujukan [12] mengemukakan bahwa aktivitas pemilahan dan pelayanan medis juga turut mempengaruhi laju timbulan.

\section{3) Pemilahan}

Pemilahan dilakukan mulai dari sumbernya sesuai dengan jenis limbah padat medis yang dihasilkan [1]. Kegiatan pemilahan di Puskesmas belum berjalan optimal. Pada kemasan limbah padat B3 masih sering ditemukan limbah domestik seperti sisa makanan, plastik, dan kertas. 


\section{4) Pengemasan}

Kemasan limbah padat B3 terbuat dari bahan yang kuat, ringan, tahan karat dan kedap air serta limbah benda tajam dikumpulkan dalam satu wadah [1] sudah terlaksana. Di setiap ruangan yang menghasilkan limbah disediakan kemasan dan menggunakan kemasan plastik sekali pakai [1] belum terlaksana. Kemasan dilengkapi penutup, simbol dan label [13] masih belum terlaksana. Penggunaan kantong kemasan limbah infeksius berwarna kuning [1] belum terlaksana.

Untuk mengetahu apakah jumlah kemasan yang tersedia sudah memenuhi atau belum makan dilakukan perhitungan kebutuhan jumlah kemasan limbah padat B3 Puskesmas. Perhitungan dilakukan pada 7 Puskesmas induk menggunakan laju timbulan masing-masing Puskesmas. Berdasarkan hasil perhitungan, jumlah kemasan yang tersedia di setiap Puskesmas sudah sesuai dengan jumlah yang dibutuhkan.

\section{5) Pengumpulan}

Pengumpulan limbah harus dilakukan setiap hari atau saat 2/3 volume kemasan sudah terisi [1]. Pengumpulan di Puskesmas induk sudah dilakukan setiap hari. Namun di Pustu pengumpulan masih dilakukan lebih dari 7 hari. Persyaratan pengumpulan menggunakan trolly pengangkut dan APD lengkap oleh petugas [1] belum terlaksana. Pengumpulan dengan segregasi [13] juga belum terlaksana.

\section{6) Penyimpanan}

Persyaratan penyimpanan maksimum 2 hari [1] belum terlaksana. Lokasi TPS bebas banjir dan tidak rawan bencana alam dan berada dalam penguasaan penghasil limbah [13] sudah terlaksana. Jarak minimum antar lokasi dengan fasilitas umum adalah $50 \mathrm{~m}$ [14] belum terlaksana. TPS memiliki saluran drainase, bak penampung, penerangan, ventilasi, dapat melindungi limbah dari sinar matahari dan hujan [13] belum terlaksana. Lantain bangunan kedap air, rata, tidak retak, serta dilengkapi simbol dan label [13] belum terlaksana. Sebagian besar TPS tidak dirancang khusus sebagai tempat penyimpanan limbah padat B3 sehingga tidak dapat memenuhi kriteria TPS B3.

Terdapat 1 Puskesmas yang tidak memiliki TPS. Limbah diletakkan di area belakang Puskesmas di ruang terbuka. Pada kondisi ini, limbah tidak akan terlidung dari sinar matahari dan hujan serta dapat diakses oleh burung, kucing, dan pemulung.

\section{7) Pengangkutan}

Pengangkutan limbah B3 dari Pustu ke Puskesmas induk atapun dari Puskesmas induk ke PT PRIA harus menggunakan kontainer yang tertutup [1]. Hal ini belum terlaksana pada pengangkutan dari Pustu ke Puskesmas induk. Pengangkutan limbah menuju pengolah sudah menggunakan kontainer yang tertutup. Petugas menggunakan APD lengkap (permen) belum terlaksana.

\section{8) Pengolahan}

Suhu minimum pembakaran limba medis adalah $1000 \mathrm{C}$ [1]. Untuk insinerator dengan tipe duble chamber, suhu pembakaran pada chamber pertama minimum $850^{\circ} \mathrm{C}$ dan suhu pembakaran di chamber kedua $1100^{\circ} \mathrm{C}$ [15]. Penelitian lainnya menyatakan insinerasi plastik dan farmasi harus dilakukan pada suhu minimum $1100^{\circ} \mathrm{C}$ [16]. Di bawah suhu ini terdapat kemungkinan terbentuknya senyawa toksik berupa dioksin dan furan. Suhu rata-rata pembakaran pada insinerator PT PRIA berdasarkan Kepmenkes 1204 (2004) sudah memenuhi persyaratan.

Berdasarkan data sekunder hasil uji emisi kedua insinerator, semua parameter sudah memenuhi baku mutu kecuali parameter dioksin dan furan. Pada uji emisi tersebut tidak dilakukan pengukuran dioksin dan furan.

\section{Rekomendasi Pengelolaan}

Berikut ini merupakan beberapa rekomendasi pengelolaan limbah padat B3 Puskesmas di Kabupaten Sidoarjo.

1. Pemilahan limbah botol infus bekas.

Botol infus makanan/obat dapat dimanfaatkan kembali dan dinyatakan sebagai limbah non B3 apabila tidak tercampur dengan limbah infeksius (pemilahan), kemudian disterilisasi, lalu selanjutnya dicacah [17].

\section{Pengadaan Safety Talk.}

Pengadaan safety talk secara rutin untuk untuk meningkatkan kesadaran mengenai penggunaan APD. Sosialisasi ini sebaiknya dilakukan terus menerus dan terjadwal sehingga seluruh karyawan, terutama yang terlibat penanganan limbah menjadi familiar dengan aturan aturan dalam Standar Operating Procedure (SOP) dan dapat melakukan dengan kesadaran sendiri tanpa paksaan [18].

\section{Menyimpan Limbah Medis pada Ruang Pendingin.}

Limbah medis dapat disimpan selama 24 jam pada suhu $20^{\circ} \mathrm{C}$ atau 72 jam pada suhu $-7^{\circ} \mathrm{C}$ hingga $-13^{\circ} \mathrm{C}$ [19]. Di California dan Mississippi limbah medis dapat disimpan maksimal 90 hari pada suhu dibawah $0^{\circ} \mathrm{C}$ (32F). Di Malaysia, fasilitas kesehatan dengan skala kecil akan menyimpan limbahnya lebih dari 1 hari dengan menyimpan limbah medis dalam pendingin bersuhu $-1^{\circ} \mathrm{C}$ hingga $-5^{\circ} \mathrm{C}$ [20]. Dengan penyimpan limbah medis di ruangan pendingin, maka limbah dapat disimpan lebih dari 2 hari.

\section{KESIMPULAN}

Kesimpulan yang dapat diambil dari penelitian ini adalah sebagai berikut.

1) Komposisi limbah padat B3 terbesar pada Puskesmas rawat inap adalah botol infus bekas 59\%, pada Puskesmas rawat jalan adalah infeksius non benda tajam $73 \%$, dan pada Pustu adalah infeksius benda tajam 39\%. Laju timbulan pada rawat inap adalah 60,47 g/pasien.hari, 
rawat jalan 6,37 g/pasien.hari dan Pustu 1,97 g/pasien.hari

2) Kondisi eksisting pengelolaan limbah padat B3 di Puskesmas dan penggunaan APD belum berjalan optimal.

3) Rekomendasi yang diberikan adalah penggunaan ruang pendingin dengah suhu dibawah $0^{\circ} \mathrm{C}$ di setiap Puskesmas sebagai TPS, pemilahan limbah bekas botol infus dan safety talk yang diadakan secara rutin.

\section{SARAN}

Saran yang diberikan untuk penelitian berikutnya adalah:

1) Selain Pustu, Puskesmas di Kabupaten Sidoarjo juga memiliki jaringan pelayanan fasilitas kesehatan seperti Ponkesdes, Polindes dan Bidan desa. Sebaiknya penelitian juga dilakukan di Ponkesdes, Polindes, dan Bidan desa.

2) Observasi lapangan mengenai rute pengangkutan limbah pada B3 dari Puskesmas di Kabupaten Sidoarjo ke pengolah sebaiknya juga dilakukan.

\section{UCAPAN TERIMA KASIH}

Penulis mengucapkan terima kasih kepada Dinas Kesehatan Kabupaten Sidoarjo dan seluruh Puskesmas di Kabupaten Sidoarjo yang telah memberikan ijin dan membantu selama proses pengerjaan penelitian .

\section{DAFTAR PUSTAKA}

[1] Direktorat Jendral Pemberantasan Penyakit Menular dan Penyehatan Lingkungan. 2004. Keputusan Menteri Kesehatan RI No. 1204/MenKes/SK/X/2004 tentang Persyaratan Kesehatan Lingkungan Rumah Sakit. Departemen Kesehatan Republik Indonesia, Jakarta, Indonesia.

[2] El-Salam, Magda Magdy Abd. 2005. Hospital waste management in ElBeheira Governorate, Egypt. Journal of Environmental Management 91, p618-629

[3] Widiartha, Komang Y. 2012. Analisis Sistem Pengelolaan Limbah Medis Puskesmas di Kabupaten Jember. Program Studi Kesehatan Lingkugan dan Kesehatan Keselamatan Kerja. FKM: Universitas Jember.

[4] ICRC, 2011. Medical Waste Management. International Committee of the Red Cross, Geneva, Switzerland.

[5] Blenkharn, J.I. 2006. Standards of clinical waste management in UK hospitals. Journal of Hospital Infection, 62, p300-303.

[6] Pruess, A., Giroult, E., Rushbrook, P. 1999. Safer management of wastes from healthcare activities. World Health Organization Geneva.

[7] Garcia, R.1999. Effective cost-reduction strategies in the management of medical waste. Am. J. Infect. Control 27 (2), p165-175.

[8] Paraningrum, Epifani Ardysta. 2011. Identifikasi Pola Penyebaran Limbah Padat B3 dari Fasilitas Kesehatan di Surabaya Barat. Program Studi Teknik Lingkungan, Institut Teknologi Sepuluh Nopember, Surabaya.

[9] Perdani, Intan Puteri. 2011. Identifikasi Pola Penyebaran Limbah Padat B3 dari Fasilitas Kesehatan di Surabaya Timur. Program Studi Teknik Lingkungan, Institut Teknologi Sepuluh Nopember, Surabaya.

[10] Pratiwi, Dyah. 2013. Analisis Pengelolaan Limbah Medis Padat Puskesmas Kabupaten Pati. Program Studi Kesehatan Masyarakat, Universitas Negeri Semarang, Semarang.

[11] Komilis, D., Fouki, A., Papadopoulos, D. 2012. Hazardous medical waste generation rates of different categories of health-care facilities. Waste Manag. 32, p1434-1441.

[12] Jang, Y., Lee, C., Yoon, O., Kim, H. 2006. Medical waste management in Korea. Journal of Environment Management 80, p107-115
[13] Sekretariat Bapedal. 2014. Peraturan Pemerintah Republik Indonesia No.101 Tahun 2014 tentang Pengelolaan Limbah Bahan Berbahaya dan Beracun. Badan Pengendalian Dampak Lingkunga, Indonesia. .

[14] Kepala Badan Pengendalian Dampak Lingkungan. 1995. Keputusan Kepada Bapedal No.1 Tahun 1995 tentang Tata Cara dan Persyaratan Teknis Penyimpanan dan Pengumpulan Limbah Bahan Berbahaya dan Beracun. Badang Pengendalian Dampak Lingkungan, Indonesia.

[15] Mohee, R. 2005. Medical wastes characterization in healthcare institutions in Mauritius. Waste Management 25, p575-581.

[16] Thornton, T. 2003. Clinical waste management in Indonesia - Issues relevant to Developing countries and best practices. In: Sustainability in a New World, ISWA World Congress 2003, Melbourne.

[17] Surat Kementrian Lingkungan Hidup Deputi Bidang Pengelolaan B3 No. 6251/Dep.IV/LH/PDAL/05/2013 perihal Klarifikasi terkait Limbah Botol Infus Bekas. Kementerian Lingkungan Hidup, Indonesia

[18] Alamsyah, Bestari. 2007. Pengelolaan Limbah Di Rumah Sakit Pupuk Kaltim Bontang untuk Memenuhi Baku Mutu Lingkungan, Tesis. Universitas Diponegoro: Semarang.

[19] Kocasoy, G. 1995. Handling and disposal of hospital wastes. In: A paper presented in the symposium on solid waste management in the Mediterranean countries, Cairo, Egypt 8-14 September.

[20] Razali, S.S., Ishak, M.B. 2010. Clinical waste handling and obstacle in Malaysia. J.of Urban and Environmental Engingeering, p47-54. 